\title{
Fostering capacity building among groups of disadvantaged farmers, southeastern North Carolina (USA)
}

\author{
Kathi Beratan ${ }^{a *}$ \\ North Carolina State University \\ Pamela Jackson ${ }^{\mathrm{b}}$ \\ Fayetteville State University \\ Sherrie Godette ${ }^{\mathrm{c}}$ \\ North Carolina State University
}

Submitted August 1, 2013 / Revised November 1, December 11, and December 13, 2013 /

Accepted December 13, 2013 / Published online April 28, 2014

Citation: Beratan, K., Jackson, P., \& Godette, S. (2014). Fostering capacity building among groups of

disadvantaged farmers, southeastern North Carolina (USA). Journal of Agriculture, Food Systems, and

Community Development, 4(3), 61-78. http://dx.doi.org/10.5304/jafscd.2014.043.001

Copyright (C) 2014 by New Leaf Associates, Inc.

\begin{abstract}
We present preliminary results from a qualitative comparative case study involving small-scale and disadvantaged (predominantly African American)
\end{abstract}

* Corresponding author: Kathi Beratan; +1-919-824-8918; Kathi Beratan@ncsu.edu

${ }^{a}$ Department of Forestry and Environmental Resources, College of Natural Resources, North Carolina State University; Raleigh, North Carolina 27695-8008 USA.

b School of Business and Economics, Fayetteville State University; 1200 Murchison Road; Fayetteville, North Carolina 28301 USA.

${ }^{c}$ Department of Public Administration, School of Public and International Affairs, North Carolina State University; Raleigh North Carolina 27695-8102 USA.

Note: Funding for this project was provided by the USDA National Institute of Food And Agriculture (NIFA) through the Agriculture and Food Research Initiative (AFRI)

Foundational Program (Award No. 2011-67023-30061). farmers in southeastern North Carolina. Agricultural assistance organizations have promoted development of farmer cooperatives as an adaptive strategy for these farmers, with only limited success. This research explores factors that contribute to or detract from the capacity of disadvantaged rural households to take advantage of new opportunities, and the role of both tangible intangible assets in shaping outcomes. We gained rich insights about these factors through the provision of tangible assets and business planning assistance to four small groups of disadvantaged farmers attempting to adopt the innovation of collaboration. Provision of tangible assets is insufficient to ensure success; our findings suggest that capacity-building efforts focused too narrowly on assets can lead assistance providers to neglect critical mediating factors that influence outcomes. A key mediating factor is the strength of trustbased relationships among group members and 
between groups and assistance providers; establishment of such relationships is a necessary precursor to cooperation and capacity development. One implication is that assistance organizations might improve outcomes of programs aimed at disadvantaged populations by focusing on trustbuilding interactions and by providing coaching and facilitation services.

\section{Keywords}

capacity building, cooperatives, disadvantaged farmers, extension, sustainable livelihoods

\section{Introduction}

Agriculture has experienced dramatic changes over several decades due to globalization and consolidation, leading to profound economic and social changes in rural communities (Drabenstott, 2003; Drabenstott \& Smith, 1996; Lobao \& Meyer, 2001; MacDonald, 2013). Particularly in the 1970s and 1980s, this structural shift contributed to lower incomes, higher levels of poverty, lower educational levels, and social and economic inequality between ethnic groups in rural communities (MacCannell, 1983). More recently, rural economies in many parts of the U.S. have benefited from increased economic diversification (Irwin, Isserman, Kilkenny, \& Partridge, 2010) and blurring of the urban-rural boundary (Lichter \& Brown, 2011). However, rural regions with large African American or American Indian populations do very poorly (Irwin et al., 2010), and the rural poor are spatially concentrated, geographically isolated, and seemingly resistant to effective policy interventions (Lichter \& Brown, 2011).

According to the U.S. Department of Agriculture (USDA), local food and direct marketing opportunities are one of the fastest growing segments of agriculture (USDA, 2013). The 2007 Census of Agriculture documents a substantial increase in direct-to-consumer markets, with direct sales rising nationally from US $\$ 812$ million in 2002 to US $\$ 1.2$ billion in 2007. Farmers' markets are becoming more abundant; 8,161 farmers markets were listed in the USDA's National Farmers Market Directory in October 2013, up from about 5,000 in 2008. North Carolina has participated in this growth; in 2010, the state was tenth among states with the most farmers' markets. In recognition of the economic opportunities provided by growing consumer demand for locally grown food, the North Carolina Sustainable Local Food Advisory Council was established by the North Carolina General Assembly in 2009 to recommend policies to benefit local food and farming.

Rapid expansion of market demand for locally and sustainably grown food is creating new opportunities for small-scale farms. However, adapting existing operations to serve these expanding markets can be very difficult and financially risky. In response, many state-level agencies and agricultural assistance organizations have expanded programs for small-scale farms selling through direct markets. These programs have benefitted farms located near metropolitan centers, but have had much less impact in rural areas.

Adaptation to changing market demand occurs through the adoption of new practices, including new ways of managing finances, natural resources, and markets (Kilpatrick \& Falk, 2001), and then innovating to adapt them to fit the particularities of a farm operation. Such adaptation appears to be particularly difficult for disadvantaged farmers, including African American farmers and those with limited resources. These farmers have been hesitant to participate in direct-marketing ventures (Colverson, 2002). Only 13 percent of limitedresource farmers use government programs as compared to 30 percent of all small-scale farmers (Steele, 1997). Studies of forestry extension efforts found low participation in government conservation and forest management programs among limited-resource landowners (Onianwa, Wheelock, Gyawali, Gan, Dubois, \& Schelhas, 2004). Disadvantaged farmers reportedly pose a particular outreach challenge for Cooperative Extension because of lack of interest, limited capital and other resources, programs not targeted to their needs, and ineffective outreach methods (Tubene \& Holder, 2001).

Agricultural assistance providers have encouraged low-resource and minority farmers to form cooperatives and work together to adapt to changing markets. A cooperative strategy should be a good fit for rural African Americans, given their long and strong history of cooperative ownership 
(Nembhard, 2004). However, few cooperative groups have been formed in North Carolina, and the success rate among those few examples has been low.

In general, there has been little recent research focused on rural communities in the U.S. Research is particularly lacking on livelihood activities of African Americans and other disadvantaged populations in rural regions (Aspaas, 2004). Thus, relatively little is known about the factors contributing to or detracting from success of African American farmers. This knowledge gap hinders efforts to assist these farmers to adapt to changes in the food system.

In this paper, we present preliminary results from research designed to address this knowledge gap. This research explores ways in which agricultural assistance organizations can more effectively help farmers from disadvantaged populations build the capacity to recognize and take advantage of new entrepreneurial opportunities and work together to overcome barriers to success.

\section{Background}

\section{Discriminatory Lending}

The history of discriminatory lending experienced by disadvantaged farmers, particularly Black farmers, is important context for our work. Ongoing access to credit is essential to farm operations, even those not seeking to expand; producers use shortterm operating credit to purchase production inputs (Carpenter, 2012). In general, Black entrepreneurs encounter more difficulties when attempting to access traditional bank loans and other sources of external finance (Chatterji \& Seamans, 2012). In the agricultural sector, discrimination has been an ongoing problem at the USDA for decades (Carpenter, 2012). Such institutionalized racial discrimination within federally sponsored programs has seriously affected the employment of African Americans as farm agents, the information farmers received regarding farm technologies and techniques, and the quantity and quality of participation within farm programs and local farm committees (Grant, Wood, \& Wright, 2012). Discriminatory lending is associated with farmland loss, such that the number of Black farm- ers in the U.S. has fallen at a much higher rate than that of White farmers (Balvanz et al., 2011). In recognition of this, a given proportion of guaranteed lending to farmers by the federal government is targeted to "socially disadvantaged applicants"; this category is defined by the USDA as those who have been subject to racial, ethnic, or gender prejudice because of their identity as members of a group without regard to their individual qualities.

\section{Cooperatives}

Cooperative enterprises are thought to enable small-scale farmers to better compete in the marketplace and to enhance their ability to observe market signals and respond to them (Ling, 2012). Cooperative development has been recommended increasingly as an economic development strategy for disadvantaged communities (Nembhard, 2004).

Despite the promise of agricultural cooperatives, many such groups in the Deep South ${ }^{1}$ have been unsuccessful historically (Sullivan, Williams, $\&$ McLin, 2012). Development of a cooperative does not guarantee long-term success, and many cooperatives are organizationally fragile and strategically vulnerable businesses (Hilchey, Gillespie, \& Henehan, 2006). Few scholars have explored how cooperative ownership actually creates and builds wealth (Nembhard, 2002, 2004).

The literature includes two different ways of thinking about cooperatives: as a business form, or as an expression of collective action that has an economic focus. The second framing is particularly relevant to African Americans, reflecting a history where formation of cooperatives was an adaptive response to systematic discrimination and persistent disadvantage (Nembhard, 2004). The potential nonmonetary value of farmer groups can be tied to social capital theory; social interactions link the individual to the wider community and affect access to opportunities and resources (Harper \& Marcus, 2003).

\footnotetext{
${ }^{1}$ In their study of farmers in the Deep south, Sullivan, Williams, \& McLin (2010) considered the Deep South to include Alabama, Georgia, Louisiana, Mississippi, and South Carolina, all states with high concentrations of historically disadvantaged farmers.
} 
Intangible Assets

Many community and rural development organizations and researchers advocate an asset-based approach to community and rural development (Pender, Marré, \& Reeder, 2012). Rather than focusing on incapacities, these approaches build on the capacities, skills, and assets of people within lower=- income communities (Kretzmann \& McKnight, 1996; McKnight \& Kretzmann, 1997). The sustainable livelihoods (SL) concept was developed by international development researchers in the early 1990s to provide a holistic approach to understanding and addressing poverty. A livelihood comprises the capabilities, assets (stores, resources, claims, and access) and activities required for a means of living (Chambers \& Conway, 1992). In order to create livelihoods, people make use of the livelihood assets or "capital" endowments they have access to and control over. Scoones summarized the SL approach as follows: "Given a particular context, what combination of livelihood resources result in the ability to follow what combination of livelihood strategies with what outcomes? Of particular interest in this framework are the institutional processes which mediate the ability to carry out such strategies and achieve (or not) such outcomes" (1998, p. 3).

Drawing from sustainable livelihoods concepts, wealth creation has recently been proposed as a useful framework for guiding strategic planning for rural development. Pender, Weber, and Fawbush define wealth comprehensively as "the stock of all assets, net of liabilities, that can contribute to the well-being of an individual or a group" (2012, p. 2). Local actors' endowments of different types of wealth determine what opportunities are available and the attendant costs, returns, risks, and constraints. These decisions are also affected by the economic, institutional, and policy context.

Although the "concepts of wealth and wealth creation apply to individuals, households, businesses, communities, regions, States, and nations" (Pender, Marré, \& Reeder, 2012, p. 4), they have been most fully developed at the community level.

Both the sustainable livelihoods and rural wealth creation (RWC) frameworks posit that wealth creation and livelihood choices are shaped by an actor's asset portfolio, and that larger-scale conditions and events form a context that influence the outcomes of the choices made by individuals and outcomes. The frameworks do not adequately explain, however, why different individuals are likely to have very different livelihood outcomes despite starting with similar portfolios of physical goods and financial assets. Asset-based development approaches try to deal with this by including human, social, and cultural factors as intangible assets within the asset portfolio.

Since poor households generally lack tangible assets, intangible assets of necessity form the basis of such households' livelihood strategies. A challenge for research and intervention design is that such intangible assets are notoriously difficult to measure.

\section{Research Questions}

To increase program effectiveness, agricultural assistance providers need a greater understanding of what aspects of current outreach and assistance approaches are not effective with disadvantaged populations, and why. Our research addresses two research questions relevant to this need:

1. What factors contribute to or detract from the capacity of disadvantaged rural households to adapt their practices to take advantage of new opportunities?

2. What role do intangible assets play in livelihood decisions and outcomes, and how can they be enhanced?

\section{A Priori Research Hypotheses}

The a priori hypotheses that shaped our research design were derived from social capital concepts. Social relations of cooperation and trust among suppliers, producers, workers, brokers, retailers, and consumers have been identified as a primary contributor to the viability of regional food business networks (Jarosz, 2000). Social capital is most simply defined as the norms and networks that enable people to act collectively (Woolcock \& Narayan, 2000). In this network view, participation in and control of information diffusion plays a critical role in the formation and use of social capital, and networks are social-capital resources that are drawn upon in learning to manage change. 
Networks are formed and maintained through interaction, and the isolation experienced by many living and working in rural areas reduces the opportunity to build information and support networks (Kilpatrick \& Falk, 2001). In urban settings, members of disadvantaged communities have been found to have small, homophilic, and very tight-knit social networks, resulting in reduced size of discussion networks, increased social isolation, and reduced access to social resources via individuals' networks of close ties (Tigges, Browne, \& Green, 1998). In general, dense bonding ties or horizontal, internal networks, combined with the absence of bridging and linking ties (external links), tend to have a negative effect on social capability (Knack \& Keefer, 1997). We therefore hypothesized that a lack of connections to business and knowledge networks outside of their close-knit social networks may be an important factor limiting the capacity of members of disadvantaged rural populations to recognize opportunities and adapt to change.

Trust between network members has been suggested as a key determining factor for achieving viable network outcomes (Smith \& Holmes, 1997). This implies that that the potential for outside intervention in the creation of groups or networks is limited in the absence of trust-based network ties (Lyon, 2000). The associational interfaces that make up any business network are vulnerable to internal and externally generated disruptions; where such interfaces do not exist or have broken down, it may take many years to rebuild relationships and trust to a point where actors across a supply chain can create the conditions necessary to interact effectively and efficiently (Marsden, Banks, \& Bristow, 2000). A long history of discrimination against disadvantaged households by government agencies and business networks has deeply eroded their trust. For example, research on the working poor during the post-Hurricane Katrina diaspora showed that this group had the most difficulty recovering from the disaster; distrust of government due to past experience of discrimination caused them to shy away from official agencies offering disaster assistance (Olson, 2007).

Face-to-face interaction is fundamental to building trust that enables collective action (Warren, 2001). We therefore hypothesized that interventions aimed at network expansion will be most effective if they emphasize interactive opportunities through which trust can be built.

The research team recognized that some level of trust was necessary to simply gain a hearing with potential participant groups. Our research design drew from research on social capital formation, which has found that the central roles of trust and information diffusion mean that brokerage opportunities are important (Burt, 2000). People filling brokerage roles can serve as access points for those seeking to provide information to a social network. We hypothesized that we could expedite the trustbuilding process by being introduced to potential study participants by assistance providers who had already earned trust by working with the groups; by "borrowing" trust, we could buy time to earn trust through a bistory of interaction.

\section{Methods}

\section{Approach}

The research follows a qualitative comparative case study approach aimed at building theory from empirical evidence (Eisenhardt, 1989; Eisenhardt \& Graebner, 2007; Yin, 1994). The research design centered on providing tangible assets in the form of an enterprise development grant of US $\$ 20,000$ per group and technical assistance with business planning from the research team. In the course of a facilitated decision process, the research team introduced the groups to appropriate and potentially useful business contacts and information providers with the goal of expanding their business networks. By assisting the groups in this process, the research team has gained rich insights into the nature of innovation capacity and the factors shaping the groups' livelihood decisions and outcomes, including the roles of intangible assets and of social relationships and networks.

\section{Methods}

The selected cases were linked through a focus on the same innovation: individuals or households engaged in an effort to adopt the innovation of developing collective enterprises. We conducted exploratory key informant interviews with staff from governmental and nongovernmental assistance organizations with special expertise in 
working with limited-resource and minority rural households. Based on the key informant input, we recruited recently convened groups whose members are predominantly from disadvantaged populations, demonstrate strong interest in working together toward one or more common farmrelated goals, and have a focus on fruit and/or vegetable production. Only a very few groups meeting these criteria were known to our key informants.

In keeping with our a priori hypotheses, the research team and the study were introduced to each selected group and endorsed by the key informant who had been working with that group. In this way, the research team was able to both respect and benefit from established relationships of trust and reciprocity.

Multiple qualitative data collection methods were used, including semistructured interviews, participant observation of group meetings, and site visits. A qualified individual who was not a member of the research team conducted baseline interviews with the participating group members while the research team focused on building sound working relationships with the groups. This "insider-outsider" structure was intended to insulate data collection from researcher bias while allowing the team to make use of the relationshipbuilding window of opportunity provided by the introductions from trusted assistance providers.

Providing technical assistance as part of the intervention allowed the research team to participate in the groups' decision-making processes, thereby developing a rich understanding of the decision context as well as the groups' situations, concerns, values, and interactional dynamics. Frequent discussions among the members of the research team were used to share observations and for iterative formation and testing of working hypotheses, allowing for constant comparison. The use of multiple investigators provided some protection against confirmation bias (Eisenhardt, 1989). Within-case data analysis enabled the researchers to become familiar with members of each group, while cross-case comparisons provided insights into the similarities and differences between each group.

It is important to note that our groups may not be representative of the larger population of disadvantaged rural households. Our study participants are members of groups in the process of developing cooperative arrangements. Since it appears to be rare for disadvantaged farmers to choose to work together cooperatively, our participants are likely to be more cooperative and more willing to innovate than is typical for the larger population. Our case selection therefore can be considered as having followed a 'critical case' strategy (Flyvbjerg, 2011), in that the individual participants have demonstrated a higher adaptive capacity than typical through their voluntary membership in a group. The higher-than-average potential for a positive outcome from the intervention increases the importance of negative results and identified barriers to success of participants' business enterprises.

\section{Findings}

\section{Group Characteristics}

The four groups included in this study are useful for a comparative case study approach as both differences and overlaps in a number of potentially important characteristics occur both within and between groups. These include geographic location of and spread among the members of each group; age; race; gender; past job experience including experience with farming; time spent living outside of the community in which they now reside; and amount of land owned, and in individual and group livelihood goals. Descriptive characteristics of the participating groups are summarized in Table 1.

The members of Groups 1, 2, and 4 are entirely or predominantly African American whereas the members of Group 3 are Caucasian. Groups 1 and 4 are most similar in terms of age, farm size, gender, and experience. Members of Groups 1 and 4 are male; there are many women in Groups 2 and 3. Group 2 includes mostly retirees, and Group 4 is the youngest. Groups 1 and 4 include some military veterans. Groups 1 and 2 are from the same geographic area and share similar soil and weather conditions. Members of Groups 2 and 3 share a particular interest in sustainable agricultural practices. The members of Groups 1, 2, and 3 are from counties classified as "rural" by the 


\section{Table 1. Summary of Group Characteristics}

The "Number of group members" category shows change in membership between the start and the end of the second year of the research project. All other information was collected at the start of the project.

\begin{tabular}{|c|c|c|c|c|}
\hline & Group 1 & Group 2 & Group 3 & Group 4 \\
\hline Year group formed & 2009 & 2010 & 2010 & 2011 \\
\hline $\begin{array}{l}\text { Number of group } \\
\text { members } \\
\text { (Initial / Current) }\end{array}$ & $6 / 3$ & $10 / 10$ & $\begin{array}{l}3 \text { / } 1 \text { original member } \\
\text { with } 2 \text { new nonfarmer } \\
\text { members }\end{array}$ & $5 / 3$ \\
\hline Age range & mid-50s to early 70 s & mid-60s to early 70 s & mid-40s to mid-50s & mid-50s to mid-60s \\
\hline Composition & $\begin{array}{l}\text { All are African } \\
\text { Americans }\end{array}$ & $\begin{array}{l}7 \text { African Americans, } \\
1 \text { Caucasian, } \\
1 \text { Hispanic }\end{array}$ & All are Caucasian & $\begin{array}{l}\text { All are African } \\
\text { Americans }\end{array}$ \\
\hline $\begin{array}{l}\text { Farm size range } \\
\text { (Farmed acreage } \\
\text { owned } \\
\text { by household) }\end{array}$ & $\begin{array}{l}32-80 \text { acres } \\
(13-32 \text { ha) } \\
\text { (avg. }=46 \text { acres or } \\
19 \text { ha) }\end{array}$ & $\begin{array}{l}1-80 \text { acres } \\
(0.4-32 \text { ha) } \\
\text { (avg. excluding one } \\
80 \text {-acre farm }= \\
4 \text { acres or } 2 \text { ha) }\end{array}$ & $\begin{array}{l}<10 \text { acres per farm } \\
(<4 \text { ha })\end{array}$ & $\begin{array}{l}2-22 \text { acres } \\
(0.8-9 \text { ha) } \\
\text { (avg. = } 12 \text { acres or } \\
5 \text { ha) }\end{array}$ \\
\hline $\begin{array}{l}\text { Number of members } \\
\text { with past farming } \\
\text { experience }\end{array}$ & $\begin{array}{l}2 \text { have farmed all } \\
\text { their lives (row } \\
\text { cropping); } 2 \text { others } \\
\text { are from farming } \\
\text { families }\end{array}$ & $\begin{array}{l}2 \text { have farmed all } \\
\text { their lives; } 5 \text { others } \\
\text { are from farming } \\
\text { families }\end{array}$ & $\begin{array}{l}\text { None has more than } \\
\text { a few years' } \\
\text { experience }\end{array}$ & $\begin{array}{l}2 \text { have extensive } \\
\text { experience on small } \\
\text { farms }\end{array}$ \\
\hline $\begin{array}{l}\text { Portion of income } \\
\text { from farming }\end{array}$ & $\begin{array}{l}0 \%, 0 \%, 0 \%, 25 \%, \\
50 \%, 100 \%\end{array}$ & $\begin{array}{l}\text { Only } 1 \text { currently } \\
\text { selling produce }\end{array}$ & $100 \%$ & $\begin{array}{l}3 \text { get little, } 2 \text { depend } \\
\text { more on farming }\end{array}$ \\
\hline Cooperative project & $\begin{array}{l}\text { Commercial-scale } \\
\text { production of } \\
\text { specialty products }\end{array}$ & $\begin{array}{l}\text { Chicken hatching and } \\
\text { organic feed mix, } \\
\text { refrigerated trailer }\end{array}$ & Farmers' market & $\begin{array}{l}\text { Joint farmstand in } \\
\text { nearby urban area }\end{array}$ \\
\hline
\end{tabular}

North Carolina Rural Economic Development Center. Groups 1, 2, and 4 are from counties in the "Black Belt" of the southeastern United States. ${ }^{2}$

The four groups had much in common with regard to motivations and capabilities; however, some differences were observed. The most notable of these are described below and summarized in Table 2. Technical assistance provided to each group is summarized in Table 3.

When asked to define what "success" means to them, all four groups focused on short-term economic survival. Expressions of this included, "It's if you can get from one year to the next without borrowing money" and "I'd like to be in a situation where I can pay the bills every month and have some left over to save."

2 The term "Black Belt" designates a band of 623 persistently poor, rural counties with large African American populations in the rural South, stretching across 11 states from eastern Texas through the deep South and into Virginia, roughly corresponding to the old Plantation South. Most of North Carolina's Black Belt counties are located in the Coastal Plain.
Despite their desire for increased profitability, many of the study participants also described nonmonetary values that are import to them. In particular, those participants who have chosen to focus on sustainable agricultural practices are persisting in prioritizing these values despite the financial barriers they have encountered. For example, a participant in Group 2 explained that he would like to have more income from outside sales, but not at the expense of changing production methods to those that he sees as nonsustainable. He said he would not borrow any money from a bank or do contract farming with a company, and expressed concern about exploitation by "the big man." Members of Group 3 value self-reliance highly, and consider absence of obligations to corporations to be more important than increased income from product sales. Participants indicated that choices based on these values provided them with a sense of self-worth and control over their lives. 
Table 2. Summary of Findings

\begin{tabular}{|c|c|c|c|c|}
\hline & Group 1 & Group 2 & Group 3 & Group 4 \\
\hline \multicolumn{5}{|l|}{ 1. Business goals } \\
\hline \multicolumn{5}{|l|}{ A. Monetary goals } \\
\hline $\begin{array}{l}\text { - Short-term economic } \\
\text { survival or "breaking even" }\end{array}$ & $\checkmark$ & $\checkmark$ & $\checkmark$ & $\checkmark$ \\
\hline $\begin{array}{l}\text { - More profitable activities } \\
\text { permitting reduced workload }\end{array}$ & $\checkmark$ & & & $\checkmark$ \\
\hline \multicolumn{5}{|l|}{ B. Nonmonetary goals } \\
\hline - Sustainable practices & & $\checkmark$ & $\checkmark$ & \\
\hline - Self-sufficiency & $\checkmark$ & $\checkmark$ & $\checkmark *$ & $\checkmark$ \\
\hline $\begin{array}{l}\text { - Leaving something of value } \\
\text { for their children }\end{array}$ & $\checkmark$ & $\checkmark$ & $\checkmark$ & $\checkmark$ \\
\hline 2. Pre-existing social ties & $\begin{array}{l}\text { Some contact, but } \\
\text { not close ties }\end{array}$ & None & None & $\begin{array}{l}\text { Some contact, but } \\
\text { not close ties }\end{array}$ \\
\hline 3. Reason for group formation & $\begin{array}{l}\text { Identification of } \\
\text { potential collective } \\
\text { enterprise }\end{array}$ & $\begin{array}{l}\text { Enjoyed collective } \\
\text { learning and } \\
\text { supportive } \\
\text { interactions }\end{array}$ & $\begin{array}{l}\text { Identification of } \\
\text { potential collective } \\
\text { enterprise }\end{array}$ & $\begin{array}{c}\text { Identification of } \\
\text { potential collective } \\
\text { enterprise }\end{array}$ \\
\hline 4. Leadership & \multicolumn{4}{|c|}{ None of the groups had a strong leader } \\
\hline 5. Group cohesion & Limited & High & Low & Limited \\
\hline $\begin{array}{l}\text { 6. Awareness of specialty products } \\
\text { and markets }\end{array}$ & $\begin{array}{l}\text { Focused on } \\
\text { production of a } \\
\text { specialty product } \\
\text { matched to an } \\
\text { identified market }\end{array}$ & $\begin{array}{l}\text { Varied; awareness } \\
\text { roughly correlated } \\
\text { with proximity to } \\
\text { major urban center }\end{array}$ & $\begin{array}{l}\text { Produced specialty } \\
\text { products not } \\
\text { matched to an } \\
\text { identified market }\end{array}$ & $\begin{array}{l}\text { Focused on } \\
\text { production of a } \\
\text { specialty product } \\
\text { matched to an } \\
\text { identified market }\end{array}$ \\
\hline 7. Business experience & $\begin{array}{c}\text { Agricultural business } \\
\text { experience }\end{array}$ & $\begin{array}{l}\text { Limited business } \\
\text { experience }\end{array}$ & Business experience & Business experience \\
\hline 8. Computer skills & Some & Limited & Some** & Some \\
\hline 9. Internet access & Adequate & Limited & Adequate & Adequate \\
\hline 10. Aversion to debt & High & High & Moderate & High \\
\hline $\begin{array}{l}\text { 11. View of farm assistance } \\
\text { organizations and programs }\end{array}$ & Generally negative & Generally negative & Somewhat negative & Generally negative \\
\hline
\end{tabular}

* Group 3 particularly emphasized self-sufficiency as an important goal.

** Group 3 was more comfortable than the other groups with the internet and with online communication.

Several members of Groups 1 and 4 told us that their motivation to join the group was a need to shift to more profitable farm activities:

"We have to think smaller, because you aren't going to row crop on 32 acres." (This statement followed a discussion of the low return per acre for row crops such as corn and soybeans.)

"I would like to get something that would get my kids back on the farm, I've been looking into some chicken houses. I don't expect them [the kids] to work for nothing." Groups 1 and 4 had some pre-existing social ties among members, but not close ties. The groups formed in response to ideas for specific collective enterprises that were strongly influenced by outsiders and for which planning and implementation were relatively straightforward. These two groups experienced few interactional challenges, but also experienced attrition as projects progressed and the group members learned more about the cumulative costs and benefits of the specific enterprises.

The members of Groups 2 and 3 largely lacked 


\section{Table 3. Technical Assistance Provided by the Research Team to the Participating Groups}

\begin{tabular}{cl}
\hline Group 1 & Business planning, marketing advice, information about relevant events and opportunities \\
\hline Group 2 & $\begin{array}{l}\text { Strategic planning, business planning, grant writing, information about relevant events and opportunities, } \\
\text { connection to organizational governance consultant }\end{array}$ \\
\hline Group 3 & $\begin{array}{l}\text { Business planning, marketing and market expansion, information about relevant events and opportunities; } \\
\text { connection to facilitation }\end{array}$ \\
\hline Group 4 & Business planning, marketing and market expansion, information about relevant events and opportunities \\
\hline
\end{tabular}

social ties prior to being brought together by an external convener. Group 2 formed around a general assumption that a cooperative arrangement would be beneficial to "farmers like them" rather than a particular collective venture. Contributing to planning challenges were the wide geographic distribution of the members and the diversity of the individual farm operations. Although lacking social ties prior to group convening, the members quickly developed ties and group cohesion. The planning challenges did introduce friction; the research team connected this group with a facilitative nonprofit specializing in helping disadvantaged individuals and groups with capacity building. This interaction is just getting underway, but it is notable that the group has already gained some interactional benefits through the process by which they recognized the problems and negotiated among themselves about what to do.

Group 3 came together around a collective enterprise idea that emerged from discussions of the individuals with the convener, a local assistance provider. This collective enterprise was inherently more interactional than the enterprises chosen by Groups 1 and 4, requiring much relationshipbuilding and network development. The enterprise also had a relatively high risk of failure as it involved adapting a standard business model developed for urban settings to a rural one. The group worked well with the research team during the first half of the research period, and did act on our recommendations. Results of the first selling season were discouraging to the group members, but the enterprise seemed to be on track. However, early discouragement coupled with the small size (three members) of the group led to increasing friction among the group members. Two new group members were recruited, and the research team connected the group with a trained facilitator to help them set up a more productive interactional framework. Unfortunately, this intervention did not occur until after personality conflicts had become entrenched and much within-group trust had dissipated. Two of the three original group members recently resigned from the group, and the future of the enterprise is in doubt.

The participants also varied in their awareness of the specific types of products that sell well in established direct markets. When asked what they grow, many of the participants provided generic answers such as "squash" and "greens." Although aware of some specialty varieties, such as "rainbow" chard, they had never considered growing them, and were unfamiliar with less common varieties such as "dinosaur" kale. Although demonstrating considerable knowledge about the differences in growing requirements among types and varieties of the products they grow, these participants appeared to be less aware that the difference mattered from a marketing standpoint. The study participants who live closer to urban centers and those for whom farming has been a major livelihood strategy for most of their adult lives were most aware of the value of specialty products, even though they did not generally grow and consume these products themselves. These participants and a few others have some experience with selling produce at roadside stands and farmers' markets, and so have interacted with nonhomophilic customers. In contrast, other participants were less familiar with other communities, as indicated by their lack of knowledge about the types of products that sell best in direct markets.

All four groups needed assistance with basic business tasks, such as developing a business plan, record-keeping, and preparing loan or grant appli- 
cations. The participants varied in these business skills as well as in their interest in and self-confidence regarding attainment of such skills. Factors influencing variation in this capacity include agerelated health issues, prior work experience, and both the availability of and comfort with computers and the Internet. For example, the research team observed some participants being dismissive of their own abilities with regard to business and computer skills, which reflected a lack of interest and/or lack of confidence. Comments like "Oh, I can't mess with that computer stuff" would be heard when a member of the research team would offer to help set up things like computer-based recordkeeping or web-based marketing. Some participants mentioned a lack of relevant and accessible training opportunities; few had up-todate computers or high-speed Internet connections.

None of the groups had a single strong leader. Instead, leadership appeared to be situational, with different individuals taking the lead on different projects and in different situations. In fact, we observed evidence that having too strong a leader may be counterproductive as the group members resist being pushed either by other group members or by people from outside the group. The fluidity in leadership may also contribute to the difficulty assistance providers have in working with the groups, since the appropriate point of contact may vary with circumstances.

All of the study participants were reluctant to take on debt, even when very favorable terms were offered. Two observations highlight this form of risk aversion particularly well. First, one group identified a major buyer for its product; meeting the buyer's needs would have required the group to spend approximately US $\$ 5,000$ on materials required to ramp up production. The research team arranged for the group to get a low-interest, guaranteed loan from a small business assistance program affiliated with Fayetteville (North Carolina) State University. However, despite the group's expressed interest in contracting with this customer, it did not apply for the loan and thereby lost the type of sales opportunity that had been the primary goal of the collective enterprise. Second, with the help of the research team, a member of another group became a Certified USDA Minority Farmer, making him eligible to receive up to US\$350,000 in loan guarantees. It is apparent that he values the credibility and legitimacy this certification gives him as a farmer and is especially pleased because he achieved it with virtually no assistance from local Cooperative Extension agents: "For years the extension agents passed my farm to visit [neighboring nonminority farm]... now they HAVE to stop by here because I've been certified by the USDA." He also made it clear that he has no intentions of taking on debt by applying for the available loans. In contrast, a more moderate aversion to taking on debt among members of group 3 was consistent with observed levels of risk aversion in the general population of small-scale farmers, and appeared to derive from specific personal experience rather than a more general institutional bias.

Most of the study participants expressed some degree of negativity toward farm assistance organizations and programs established to help farmers. For example, one participant noted that although he is aware that the Farm Service Agency has programs and services that he could use, he is reluctant to register his farm with the agency because he is afraid they will tell him that he needs to spend money to do something. Other farmer participants pointed to experience-based expectations of discrimination:

"Farmers, they're a close-knit group of people, and if you're not in their safety net, they are not going to reach out to you; the minority farmers have gotten used to being screwed, so they won't reach out, if you're an outsider."

"Other farmers who have been around say it [lack of notification of opportunities] is because you are a minority so the only thing the farmers are worried about is crop insurance. Anything else about these programs, we're the last to know. They had money for fencing, money for wells, but we don't hear about it....It's really hard when you can't work with your resource programs....the guy came and said we needed to do a ditch, because our land was 
holding water....I don't know if he didn't take us seriously, but we're not the only one he didn't help."

Not all agency personnel have been equally effective in connecting with these farmers. One of the more experienced farmers in our study said that he found the county extension office in his county to be very rude, "as if they don't want to be bothered." The farmer now goes out of his way to work with extension agents in another county "who are more in tune with the small local growers." Two factors appear to have contributed to this farmer's choice to go outside his county for extension services. First, this farmer lives in a more urban county than any of the others: "We need to go there [the other county] because they are more rural, and here is not rural." Second, the county extension office that this farmer now visits is home base for an Area Specialized Agent with North Carolina (NC) A\&T State University, the state's 1890 Land Grant university (a historically Black college), who is himself African American. It is interesting to note that several of the participants referred to this agent as being affiliated with NC A\&T State University but did not connect him with the Cooperative Extension Service, even though he works out of the county extension offices in the two counties he covers.

\section{Evaluation of A Priori Research Hypotheses}

Our preliminary findings support our hypothesis that a lack of connections to business and knowledge networks outside their close-knit social networks is an important factor limiting the capacity of members of disadvantaged rural populations to recognize opportunities and adapt to change. Participants had difficulty answering the question "who do you get information from regarding agricultural practices and marketing?" The primary source of information about farm programs mentioned by several participants is one specialized extension agent affiliated with NCA\&T University; however, it was notable that few of the participants remembered that this agent was affiliated with Cooperative Extension. The few participants who could readily list agencies and individuals from whom they get information were the participants who had been involved in farm- related activities throughout their adult life. In general, participants who had lived in the same area for their whole lives or who had moved back to the area some time ago made more mention of family and neighbors as sources of information and assistance, mostly in the form of labor on an occasional basis.

A factor observed to limit progress in planning group collective enterprises is a slowness to initiate or respond to inquiries and notices of opportunities; this characteristic also negatively impacted network development. One of our key informants framed the problem thusly: "the farmers move slow they need to learn to pay attention to timing." He noted that this reluctance to interact was particularly pronounced when dealing with assistance providers and others from outside the farmers' immediate social circles and was negatively impacting the farmers' efforts to build their businesses. Our informant's comments suggest that this reluctance to reach across social boundaries may be exacerbated if assistance providers do not give adequate consideration to the settings and terminology used to provide information to these farmers:

“The farmers don't like paperwork or making phone calls....Minority and small farmers don't go to meetings. The timing doesn't work. But they also get intimidated by jargon; they don't get engaged, they listen but don't process."

Although we were struck by the similarities in the groups, the predominantly African American groups did differ from the Caucasian group in the rapidity in which they acted upon information.

Relative to the Caucasian group, the African American groups communicated less frequently with the research team and were slow to follow up on information about potential opportunities. Members of the Caucasian group evidenced a higher comfort level with online communications. This likely contributed to differential response patterns but is an insufficient explanation since similar patterns were observed when information was provided in person or in letters send through the U.S. mail. It is reasonable to hypothesize that cultural factors, likely related to a history of dis- 
crimination, play a significant role in the observed "slowness" to act in the predominantly African American groups. We suggest that experience may have shown them that "looking before leaping" is smart. These groups described many experiences where they were given advice and offers of assistance but then were left "bigh and $d r y$ " midway through with little to show for the effort, or most of the benefits went to the advisor rather than to the group. One group in particular was slow to agree to participate in the study and to identify a collective enterprise. Throughout its short history as a group, assistance organizations and other outsiders have applied pressure on it to do particular things in particular ways rather than focusing on helping to build the group members' capacity to make their own decisions and strategic plans. It appears that groups of small-scale farmers, particularly those with minority memberships, present opportunities for other people and organizations that are not necessarily congruent with the groups' interests and needs. The groups have learned that they need to take time to evaluate advice they are given, as well as the motives or agenda of the person or organization providing the advice, in order to make informed and reasoned decisions. Habit and circumstances can certainly push this reasonable deliberateness too far, but it is unhelpful for assistance providers to jump to the conclusion that slowness of response is evidence of low motivation to succeed or lack of understanding.

Our experiences support the hypothesis that the trust-building process can be expedited through introductions to potential study participants by assistance providers who were working with the groups. The recommendation of the assistance provider clearly was a factor in Groups 1, 2, and 3's decision to participate in our study. It is important to note that "borrowed" trust expedited the initial stages of the project but did not eliminate the need for us to build relationships with the groups and the individual members; by "borrowing" trust, we gained time to earn trust through our actions.

These observations are consistent with previous research that has found a lack of knowledge regarding alternative production and marketing opportunities among African American farmers. This has been interpreted as reflecting a reluctance to attend meetings and trainings conducted by traditional agricultural assistance organizations that are viewed as not treating African American farmers fairly (e.g., Grant, Wood, \& Wright, 2012; Havard, 2001; Wood \& Ragar, 2012). African American farmers in North Carolina who participated in a study by Balvanz and colleagues (2011) agreed that discrimination endured by African Americans in their community deteriorated selfconfidence, which prevented them from seeking new opportunities for economic advancement since they expected further rejection.

Support was also found for the hypothesis that interventions aimed at network expansion will be most effective if they emphasize interactive opportunities through which trust can be built. The research team met with each group several times during the project's first year, most times playing an active role in the meeting but sometimes simply observing the proceedings. Each meeting served as an opportunity for the participants to assess the research team's abilities and attitudes. Mayer, Davis, and Schoorman (1995) showed how assessing partners' perceived abilities (competencies and skills); benevolence (genuine care); and integrity (principle compatibility) lays the foundation for expectations shaping trust levels. The research team understood that we needed to consistently demonstrate these three characteristics in our interactions with the groups in order to earn trust. Preliminary evidence suggests that the groups did form positive perceptions of the research team in the course of many interactions over two years. More specifically, we earned trust with the individual group members we interacted with, and that individual-level trust influenced and contributed to the collective attitude of the group toward the research team.

Members of the four groups we worked with had only limited social ties prior to group formation. There certainly was information exchange through social networks prior to the groups convening. However, limited evidence suggests that it may be rare for such informal social interactions to transition to more organized and formalized cooperative business arrangements among this population. Instead, assistance providers brought together people who expressed 
some interest in cooperative enterprises, and then pushed the groups toward formalization as farmer cooperatives without exploring group members' shared goals and interests. Some degree of selfsorting did occur through each household's decision whether to work with the convener and the other participating households, and it is likely that some degree of trust and perceived homophily contributed to this decision.

Importantly, we found that the effectiveness of external interventions is limited if trust-based relationships are not present among group members, and there was more need than anticipated for deliberate efforts to strengthen within-group relationships. We interpret this as reflecting the fact that the formation of the groups was catalyzed by outside agents rather than occurring through a process of self-organization. Groups 1 and 4 were enterprise- rather than relationship-focused, and have experienced continued attrition as individuals decided that the enterprise was not a good fit for their farm or was not meeting their expectations. The members of Group 3 did not lose interest in their collective enterprise, but serious interactional difficulties developed as personality differences overcame weakly developed relationships. The group agreed to facilitation, but too late to repair damaged relationships. Relationship-building was an important goal for Group 2; members expressed frustration with how slowly they were progressing, and were open to the research team's suggestion that they get expert assistance with structuring interactional dynamics. Two of the participating groups required a lot of coaching-type facilitation from the research team before they were able to develop a plan for spending the funds made available to them. In retrospect it is clear that all of the groups would have benefited from coaching on within-group interactions.

\section{Discussion}

Our findings show that simply providing tangible assets is insufficient to ensure that individuals or groups will or can take advantage of those resources. The asset portfolio is certainly important, and lack of assets is a limiting factor in enterprise development for this population, but other factors mediate the use of assets. We observed similar patterns with intangible assets such as trust (among group members, and between group members and assistance providers and business contacts) being also necessary but not sufficient to trigger action. Our findings echo those of Grim (1995), who found that African American farmers did not view farming as a business and lacked business connections necessary to develop their farm operations. We found that this is still true, and that it reflects a deep aversion to risk derived from a long history of institutional discrimination and resulting lack of trust. Our study participants want to expand their farm operations, but only to the extent that their personal finances can take them. They are comfortable with informal cooperative arrangements where they borrow each other's equipment and sell to each other at wholesale prices, but they are not interested in pooling resources or establishing more formal business arrangements. Notably, they do not want to assume debt even when loans are low-risk and are both appropriate and necessary for their business development. Lack of trust in formal institutions is a contributing factor; these farmers do not trust agricultural assistance programs or other programs designed to support the business community, and view participation in such programs as unacceptably risky.

An individual's business decisions are influenced by individual characteristics as well as community- or population-level factors. In addition to a particular combination of assets, each individual has a particular set of capacities and capacity gaps that reflect a unique life history and combination of personal attributes. Examples of personal characteristics that have previously been found to influence individual and household choices and outcomes include risk aversion and willingness to trust new acquaintances (e.g., Grothmann \& Patt, 2005; Howard \& Roe, 2011; Pyysiäinen, Anderson, McElwee, \& Vesala, 2006; Shane, 2003; Sriram, Mersha, \& Herron, 2007). Some researchers and practitioners in the fields of livelihoods and RWC have classified such characteristics as buman or social assets, and thus included them within the asset portfolio. For purposes of assistance program design, we suggest that it is more useful to think of these characteristics as mediating factors that influence whether the individual's or household's 
existing assets get turned into activities and outputs constituting a livelihood strategy. Definitions included in the foundational SL literature are consistent with this interpretation; for example, in Carney's definition, "a livelihood comprises the capabilities, assets (including both material and social resources) and activities required for a means of living" (1998, p. 4). What we refer to as personal characteristics contribute to "capabilities."

One significant limitation of both the SL concept and the RWC framework as guides for intervention design is that they focus insufficient attention to the role of individual capabilities in shaping livelihood decisions and implementation efforts. However, such personal characteristics are important mediating factors that lead to differential outcomes despite similar wealth assets and contextual factors. The individual participants in this study exhibited a range of personal traits and viewpoints that appear to be shaping their selection of livelihood strategies and the outcomes they achieve. These include individual willingness to reach out to people and organizations outside their immediate social circle for information, the intensity of their entrepreneurial ambition, and their willingness to seek out and adopt new practices and livelihood strategies. Farm assistance programs work directly with individual farmers and farmer groups with the goal of improving farm profitability and the well-being of farm families. These programs therefore are likely to fail to meet their objectives if they focus exclusively on assets during intervention design without consideration of mediating factors that influence outcomes. A balance is needed.

Our observations are consistent with Flora and Flora's (1993) concept of entrepreneurial social infrastructure as a necessary link between physical resources and leadership for community development, with social infrastructure defined as the group-level, interactive aspect of organizations or institutions. This concept has largely been subsumed into social capital research, with entrepreneurial social infrastructure included as a specific configuration of social capital (e.g., Emery \& Flora, 2006); we suggest that the mediating role highlighted in the original concept is important and should not be discounted.
We developed the following recommendations based on our observations of and comparison among our four groups:

- Pre-existing social ties and/or opportunities for interaction prior to group formation permit individuals to evaluate compatibility of personalities, values, and goals. This can foster development of trust-based relationships necessary for group cohesion and effective cooperation.

- People differ in their goals and interests; individuals' continued willingness to participate in group activities will depend on the degree of overlap they perceive between their individual interests and those of the other group members.

- Few people have the natural skill or training to manage interactional dynamics effectively. Therefore most newly formed groups would benefit from expert facilitation as the members begin to share information, identify common goals, and develop interactional rules and organizational arrangements.

- Assistance providers should not adopt a one-size-fits-all approach to cooperative development. Individual group members can operate independently and yet productively engage in a wide array of shared activities that create synergy among group members and increase revenues.

- Each group of cooperating individuals will have a particular mix of interests, skills, and personalities. This means that groups will likely differ in the interactional styles and organizational arrangements with which they are most comfortable. Some groups will be more comfortable establishing a more purely business relationship, while others will place greater value on social support. Assistance providers need to be able to recognize such differences in order to conduct more effective needs assessments and provide the most useful advice and assistance to each group. The range of expertise required might best be provided 
by multiple assistance providers working cooperatively. A holistic approach to assistance provision has the potential to be much more effective than the current practice in which one expert, in isolation, provides one type of service to disadvantaged farmers.

We plan to test the constructs underlying these recommendations in our future research.

\section{Conclusion}

Our preliminary results support a model in which an individual's capacity to innovate emerges dynamically from a complex interplay of personal characteristics, personal experience, the extent, structure, and nature of the linkages in his or her social and information networks, culture (collective experience), and chance opportunities (serendipity). When several individuals work cooperatively toward a common goal, that group will have a collective set of capabilities and capacity gaps. Capacity-sharing occurs through interaction, and so the nature of the interactions among group members will mediate the capacity exchange. Collective capacity, therefore, is not simply the sum of the individual capacities but is emergent from and dependent upon the complex interactions among group members. An important consequence of this for assistance organizations is that any effort to build the capacity of cooperative groups to improve wealth creation outcomes will need to take into account not only the capacities and capacity gaps of the individual group members, but also the nature of the interactions among group members.

We suggest that capacity-building efforts focused too narrowly on assets can lead assistance providers to neglect human factors that are critical in overcoming cultural and societal barriers to success, even with the inclusion of "human capital" into frameworks used for program planning. Assistance organizations might improve outcomes of programs aimed at disadvantaged populations by focusing on trust-building interactions and by providing coaching and facilitation services. In our future work, we plan to draw from the entrepreneurship and teamwork literatures to further explore these mediating factors.

\section{Acknowledgements}

We wish to thank Dr. Thomas Williams and Dr. Rebecca Dunning for their contributions to this project. We are also grateful for the encouragement and ideas provided by Donald Belk, Rev. Mac Legerton, Dr. Branda Nowell, and Dr. John Cooper. Lastly, thanks to the editor and anonymous reviewers for their helpful and constructive comments.

\section{References}

Aspaas, H. R. (2004). Minority women's microenterprises in rural areas of the United States of America: African American, Hispanic American and Native American case studies. Geojournal, 61(3), 281-289. http://dx.doi.org/10.1007/s10708-004-3689-0

Balvanz, P., Barlow, M. L., Lewis, L. M., Samuel, K., Owens, W., Parker, D. L.,...Ammerman, A. (2011). "The next generation, that's why we continue to do what we do": African American farmers speak about experiences with land ownership and loss in North Carolina. Journal of Agriculture, Food Systems, and Community Development, 1(3), 67-88. http://dx.doi.org/10.5304/jafscd.2011.013.011

Burt, R. S. (2000, July). The network structure of social capital. In B. M. Staw \& R. I. Sutton (Eds.), Research in organizational behavior (volume 22, pp. 345-423). Greenwich, Connecticut: JAI Press.

Carney, D. (1998, July). Implementing the sustainable rural livelihoods approach. In D. Carney (Ed.), Sustainable rural liveliboods: What contributions can we make? (pp. 3-23). London: Department for International Development.

Carpenter, S. (2012). The USDA discrimination cases: Pigford, in re Black Farmers, Keepseagle, Garcia, and Love. Drake Journal of Agricultural Law, 17(1), 1-35.

Chambers, R., \& Conway, G. R. (1992). Sustainable rural livelihoods: Practical concepts for the $21^{\text {st }}$ century [IDS Discussion Paper 296]. Brighton, UK: Institute for Development Studies. Retrieved from http://www.ids.ac.uk/publication/sustainablerural-livelihoods-practical-concepts-for-the-21stcentury

Chatterji, A. K., \& Seamans, R. C. (2012). Entrepreneurial finance, credit cards, and race. Journal of Financial Economics, 106(1), 182-195. http://dx.doi.org/10.1016/j.jfineco.2012.04.007 
Colverson, K. E. (2002, July). Creating a value-added marketing network for limited-resource farmers. In D. Dbodaghe \& E. Gomez (Eds.), Proceedings of the Third National Small Farm Conference. Washington, D.C.: U.S. Development of Agriculture Cooperative State Research, Education, and Extension Service and Land-Grant University System. Retrieved from http://aces.nmsu.edu/smallfarm 2002/SmallFarmProc.pdf

Drabenstott, M. (2003). A new era for rural policy. Economic Review, 88(4), 81-98.

Drabenstott, M., \& Smith, T. R. (1996). The changing economy of the rural heartland [Preface]. In Federal Reserve Bank of Kansas City, Economic forces shaping the rural heartland (pp. 1-11). Kansas City, Missouri: Federal Reserve Bank of Kansas City.

Eisenhardt, K. M. (1989). Building theories from case study research. Academy of Management Review, 14(4), 532-550. http://dx.doi.org/10.5465/AMR.1989.4308385

Eisenhardt, K. M., \& Graebner, M. E. (2007). Theory building from cases: Opportunities and challenges. Academy of Management Journal, 50(1), 25-32. http://dx.doi.org/10.5465/AMJ.2007.24160888

Emery, M., \& Flora, C. (2006). Spiraling-up: Mapping community transformation with Community Capitals Framework. Community Development, 37(1), 19-35. http://dx.doi.org/10.1080/15575330609490152

Flora, C. B., \& Flora, J. L. (1993). Entrepreneurial social infrastructure: A necessary ingredient. Annals of the American Academy of Political and Social Science, 529(1), 48-58. http://dx.doi.org/10.1177/0002716293529001005

Flyvbjerg, B. (2011). Case study. In N.K. Denzin \& Y.S. Lincoln (Eds.), The SAGE Handbook of Qualitative Research (4th Ed., pp. 301-316). Thousand Oaks, California: SAGE Publications.

Grant, G. R., Wood, S. D., \& Wright, W. J. (2012). Black farmers united: The struggle against power and principalities. Journal of Pan African Studies, 5(1), 3-22.

Grim, V. (1995). The politics of inclusion: Black farmers and the quest for agribusiness participation, 19451990. Agricultural History, 69(2), 257-271.

Grothmann, T., \& Patt, A. (2005). Adaptive capacity and human cognition: The process of individual adaptation to climate change. Global Environmental Change, 15(3), 199-213. http://dx.doi.org/10.1016/j.gloenvcha.2005.01.002

Harper, C., \& Marcus, R. (2003). Enduring poverty and the conditions of childhood: Lifecourse and intergenerational poverty transmissions. World Development, 31(3), 535-554. http://dx.doi.org/10.1016/ $\underline{\mathrm{S} 0305-750 \mathrm{X}(03) 00010-\mathrm{X}}$

Havard, C. J. (2001). African-American farmers and fair lending: Racializing rural economic space. Stanford Law and Policy Review, 12(2), 333-360. Retrieved from the National Agricultural Law Center website: http://nationalaglawcenter.org/wp-content/ uploads/assets/bibarticles/havard african.pdf

Hilchey, D., Gillespie, G., \& Henehan, B. (2006). Smallscale grower cooperatives in the Northeast United States (Rural Business Cooperative Service, RBS Research Report No. 210). Washington, D.C.: United States Department of Agriculture. Retrieved from http://www.rurdev.usda.gov/supportdocuments/ RR210.pdf

Howard, G. E., \& Roe, B. E. (2011, September). Comparing the risk attitudes of U.S. and German farmers. Paper presented at the 2011 International Congress of the European Association of Agricultural Economists, Zurich. Retrieved from http://purl.umn.edu/114528

Irwin, E. G., Isserman, A. M., Kilkenny, M., \& Partridge, M. D. (2010). A century of research on rural development and regional issues. American Journal of Agricultural Economics, 92(2), 522-553. http://dx.doi.org/10.1093/ajae/aaq008

Jarosz, L. (2000). Understanding agri-food networks as social relations. Agriculture and Human V alues, 17(3), 279-283. http://dx.doi.org/10.1023/A:1007692303118

Kilpatrick, S., \& Falk, I. (2001). Benefits for all: How learning in agriculture can build social capital in island communities (CRLRA Discussion Paper D2/2001). Launceston, Tasmania: University of Tasmania, Centre for Research and Learning in Regional Australia.

Knack, S. \& Keefer, P. (1997). Does social capital have an economic payoff? A cross-country investigation. Quarterly Journal of Economics, 112(4) 1251-1288. http://dx.doi.org/10.1162/003355300555475

Kretzmann, J., \& McKnight, J. P. (1996). Assets-based community development. National Civic Review, 85(4), 23-29. http://dx.doi.org/10.1002/ncr.4100850405 
Lichter, D. T., \& Brown, D. L. (2011). Rural America in an urban society: Changing spatial and social boundaries. Annual Review of Sociology, 37, 565-592. http://dx.doi.org/10.1146/annurev-soc-081309$\underline{150208}$

Ling, K. C. (2012). The nature of cooperatives. Rural Cooperatives, 79(1), 32-35. Retrieved from http://www.rurdev.usda.gov/BCP Coop RurCoopMag.html

Lobao, L., \& Meyer, K. (2001). The great agricultural transition: Crisis, change, and social consequences of twentieth century US farming. Annual Review of Sociology, 27, 103-124. http://dx.doi.org/10.1146/annurev.soc.27.1.103

Lyon, F. (2000). Trust, networks and norms: The creation of social capital in agricultural economies in Ghana. World Development, 28(4), 663-681. http://dx.doi.org/10.1016/S0305-750X(99) 00146-1

MacCannell, D. (1983, March). Agribusiness and the small community. In Office of Technology Assessment (Ed.), Technology, public policy and the changing structure of American agriculture [Volume IIBackground Papers, May 1986]. Washington, D.C.: Congress of the United States, Office of Technology Assessment. Retrieved from http://digital.library.unt.edu/ark:/67531/metadc 97467/m2/1/high_res_d/1001730944.pdf

MacDonald, J. (2013, September 3). Cropland consolidation and the future of family farms. Amber $W$ aves. Washington, D.C.: USDA, Economic Research Service. Retrieved from http://www.ers.usda.gov/amber-waves/2013september/cropland-consolidation-and-the-futureof-family-farms.aspx

Marsden, T., Banks, J., \& Bristow, G. (2000). Food supply chain approaches: Exploring their role in rural development. Sociologia Ruralis, 40(4), 424-438. http://dx.doi.org/10.1111/1467-9523.00158

Mayer, R. C., Davis, J. H., \& Schoorman, F. D. (1995). An integrative model of organizational trust. Academy of Management Review, 20(3), 709-734. http://dx.doi.org/10.5465/AMR.1995.9508080335

McKnight, J. L., \& Kretzmann, J. P. (1997). Mapping community capacity. In M. Minkler (Ed.), Community organizing and community building for health (3 ${ }^{\text {rd }}$ Ed., pp. 157-172). New Brunswick, New Jersey: Rutgers University Press.
Nembhard, J. G. (2002). Cooperatives and wealth accumulation: Preliminary analysis. American Economic Review, 92(2), 325-329. http://dx.doi.org/10.1257/000282802320189483

Nembhard, J. G. (2004). Cooperative ownership in the struggle for African American economic empowerment. Humanity \& Society, 28(3), 298-321. http://dx.doi.org/10.1177/016059760402800307

Olson, L. (2007). Case study of a catastrophic event Hurricane Katrina: An evaluation of social vulnerability and community/organizational resilience. In K. Warner (Ed.), Perspectives on social vulnerability (Publication Series of UNU-EHS No. 6/2007). (1 ${ }^{\text {st }}$ Ed., pp. 115-124). Bonn: United Nations University Institute for Environment and Human Security. Retrieved from http://www.ehs.unu.edu/article:336

Onianwa, O., Wheelock, G., Gyawali, B. R., Gan, J., Dubois, M., \& Schelhas, J. (2004). An analysis of factors affecting participation behavior of limited resource farmers in agricultural cost-share programs in Alabama. Journal of Agribusiness, 22(1), 17-29. http://purl.umn.edu/56848

Pender, J., Marré, A., \& Reeder, R. (2012). Rural wealth creation: Concepts, strategies, and measures (Economic Research Report No. 131). Washington, D.C.: USDA, Economic Research Service.

Pender, J., Weber, B., \& Fawbush, W. (2012). Theme overview: Rural wealth creation. Choices, 27(1). Retrieved from http://www.choicesmagazine. org/choices-magazine/theme-articles/rural-wealthcreation/theme-overview-rural-wealth-creation

Pyysiäinen, J., Anderson, A., McElwee, G., \& Vesala, K. (2006). Developing the entrepreneurial skills of farmers: Some myths explored. International Journal of Entrepreneurial Behaviour \& Research, 12(1), 21-39. http://dx.doi.org/10.1108/13552550610644463

Scoones, I. (1998). Sustainable rural livelihoods: A framework for analysis (IDS Working Paper No. 72). Brighton, UK: Institute of Development Studies.

Shane, S. (2003). A general theory of entrepreneurship: The individual-opportunity nexus. Cheltenham, UK: Edward Elgar Publishing.

Smith, S., \& Holmes, S. (1997). The role of trust in SME business network relationships. Proceedings of the U.S. Association for Small Business and Entrepreneurship World Conference. Retrieved from http://usasbe.org/ 
Sriram, V., Mersha, T., \& Herron, L. (2007). Drivers of urban entrepreneurship: An integrative model. International Journal of Entrepreneurial Behaviour \& Research, 13(4), 235-251. http://dx.doi.org/10.1108/13552550710760012

Steele, C. J. (1997). Why US agriculture and rural areas have a stake in small farms. Rural Development Perspectives, 12(2), 26-31.

Sullivan, G., Williams, A., \& McLin, K. (2012). Increasing farmer success in local food markets in the Deep South: Mississippi \& Alabama. Arlington, Virginia: Wallace Center, Winrock International. Retrieved from http://www.wallacecenter.org/increasingfarmer success/

Tigges, L. M., Browne, I., \& Green, G. P. (1998). Social isolation of the urban poor: Race, class, and neighborhood effects on social resources. Sociological Quarterly, 39(1), 53-77. http://dx.doi.org/10.1111/ j.1533-8525.1998.tb02349.x

Tubene, S., \& Holder, D. (2001). Serving small farms in the $21^{\text {st }}$ century. College Park, Maryland: Small Farm Institute, Maryland Cooperative Extension, University of Maryland. Retrieved from
https://www.agnr.umd.edu/Extension/agriculture $\angle$ smallFarms/publications.cfm

U.S. Department of Agriculture. (2013, August 5). USD A celebrates National Farmers Market Week, August 4-10; Confirms growth and sustainability in farmers markets (News Release No. 0155.13). Retrieved from http://www.usda.gov/wps/portal/usda/ usdahome? contentid $=2013 / 08 / 0155 . x m l$

Warren, M. R. (2001). Dry bones rattling: Community building to revitalize American democracy. Princeton, New Jersey: Princeton University Press.

Wood, S. D., \& Ragar, C. R. (2012). Grass tops democracy: Institutional discrimination in the civil rights violations of Black farmers. Journal of Pan African Studies, 5(6), 16-36.

Woolcock, M., \& Narayan, D. (2000). Social capital: Implications for development theory, research, and policy. World Bank Research Observer, 15(2), 225-249. http://dx.doi.org/10.1093/wbro/15.2.225

Yin, R. K. (1994). Case study research: Design and methods (2nd Ed.). Thousand Oaks, California: SAGE Publications. 